\title{
Autumn migration of soaring birds through the Gebel El Zeit Important Bird Area (IBA), Egypt, threatened by wind farm projects
}

\author{
GUDRUN HILGERLOH, ANDREAS MICHALIK and BERND RADDATZ
}

\section{Summary}

Systematic bird observations were performed during autumn 2006 in the migration bottleneck area of Zeit Bay, Egypt $\left(27.73^{\circ} \mathrm{N}, 33.51^{\circ} \mathrm{E}\right)$, situated on the coast of the Gulf of Suez, opposite southern Sinai. Owing to the strong northerly winds in that area, considerable pressure exists to construct wind farms. A total of 145,432 soaring birds, including 134,599 storks and 9,376 raptors over a period of 453.6 hours were observed between 20 August and 29 October by two teams working daily in two shifts. White Stork Ciconia ciconia and European Honey Buzzard Pernis apivorus were the most numerous species ( $91.4 \%$ and $5.7 \%$ respectively) of all soaring birds observed. As both species migrate early, relatively few birds were recorded passing through in October. A total of 57,179 soaring birds were observed within a range of $2.5 \mathrm{~km}$ from the observers, and of these 32,248 were flying at heights up to $200 \mathrm{~m}$. Few individuals of the rapidly declining breeding populations of Egyptian Vulture Neophron percnotperus ('Endangered') and Lesser Kestrel Falco naumanni ('Vulnerable') passed (8 and 33 respectively). Pallid Harriers Circus macrourus ('Near Threatened') however, were more numerous (IOO) than at other migration sites along the East African-West Asian Flyway (Israel, southern tip of Sinai, Suez and Bab-el-Mandeb). Western Marsh Harrier Circus aeruginosus and Montagu's Harrier Circus pygargus were also more numerous than at these sites. Some other large migrant species, observed at Suez, Bab el-Mandeb or in Israel, were seen only in small numbers or not at all at Zeit Bay in autumn. Among them, the Steppe Eagle Aquila nipalensis being the best known example of loop migration, entering Africa at Suez and Bab el-Mandeb, is for this reason not expected in autumn at Zeit Bay, while in spring it is a regular migrant. The number of Black Storks Ciconia nigra observed accounted for $4.8 \%$ of the flyway population, that of White Storks for 33.3\%, Great White Pelicans Pelecanus onocrotalus for a further $3.5 \%$ and European Honey Buzzards for $0.8 \%$. The extrapolation of the number of birds passing through the study area during the migration season, suggests that it was used by $92 \%$ of the White Stork, $12 \%$ of the Black Stork, $5 \%$ of the Great White Pelican, $4 \%$ of the European Honey Buzzard and $2 \%$ of the Pallid Harrier flyway populations in autumn 2006.

\section{Introduction}

The numbers and species of soaring birds present at a migration site depend to a great extent on the migration routes of those species and the extent to which they depend on thermals. Soaring birds either avoid sea crossings completely or they cross at the narrowest straits available, thus creating migration bottlenecks (Bildstein 2006). During autumn migration, the soaring birds of the East African-West Asian flyway either detour round the Gulf of Suez, passing near the city of Suez, or they move south down the Sinai Peninsula and cross the Gulf of Suez at its narrowest strait between El Tur and Gebel El Zeit or at the southern tip of Sinai. A third route leads down through the Arabian Peninsula and enters Africa at Bab-el-Mandeb (Welch and Welch 1988). 
The narrowest strait opposite the southern part of Sinai, at Zeit Bay, is recognized by ornithologists as an important migration site (Grieve 1996, Baha El Din 1999, Christensen and Jensen 2002, Hilgerloh 2008, Tammens 2008). Spring observations have shown that it is extremely important for migrants (Hilgerloh 2009, Hilgerloh et al. 2009) but, although it has long been acknowledged that the site is also of great importance during autumn migration (Baha El Din 1999), no systematic observations have previously been carried out. Birds often follow different routes in autumn and in spring (Newton 2008). However, an autumn study is needed to establish the extent to which this is true of Zeit Bay. The area is designated as an Important Bird Area (IBA) but is under threat from proposed wind farm construction. Wind farms, if placed in areas with high densities of low-flying raptors can dramatically increase mortality (Langston and Pullan 2003, Hoetker et al. 2004, Telleria 2009). In general, soaring birds lose height during a sea crossing because of the lack of thermals (Newton 2008). If birds continue migration immediately after arrival at the coast of Zeit Bay, they will remain at a low altitude while flying over the coastal plains (Baha El Din 1999) and will therefore be under threat if the proposed wind farms are built. The data in this study were collected to assess the extent of this threat.

\section{Methods}

\section{Study area}

The study was carried out in an area of c. $700 \mathrm{~km}^{2}$ situated in the coastal desert south of Ras Gharib and west and north-west of Zeit Bay (Figure $1 ; 27.73^{\circ} \mathrm{N}, 33.51^{\circ} \mathrm{E}$ ). It was bordered on the west by the foothills of the Red Sea Mountains and in the east by plains stretching to the coast and to the foothills of the mountain chain of Gebel El Zeit. Except for a salt depression (sabkha) with some open water in the north, the study area consisted entirely of dry desert. Strong northerly winds prevailed during the entire study period.

\section{Daytime field observation}

Two lines of 13 observation sites, $5 \mathrm{~km}$ apart, were aligned in an approximately NW-SE direction. The eastern line was close to the Suez-Hurghada main road and the second row was established $5 \mathrm{~km}$ west of it in the desert (Figure 1). Each site was defined by its coordinates measured by GPS. In spring, field observations were performed at the same observation sites (Hilgerloh 2009). Given an observation radius from each observation point of $2.5 \mathrm{~km}$, this created a double row of 13 observation circles succeeding one another without overlap. All observation sites were situated within the Gebel El Zeit IBA.

The observations were performed by ornithologists with more than 5 years of experience in bird identification. Two teams, each comprising two members, observed in shifts. One team worked from sunrise to noon, the other from noon to sunset, in order to ensure that all sites were visited at different times of the day. Travelling time between sites was approximately 20 minutes. Observation periods were of 60 minutes per site up to 16 September and of 40 minutes thereafter. The first team began observations at the southernmost desert site, moving successively northwards from site to site (Figure 1). The second team first visited the road site furthest north and advanced southwards. On each subsequent day, each team continued where it had left off the day before. The two teams worked alternately, thus avoiding double counts entirely, apart from a period at the beginning when the observation times of the teams overlapped; but these data were checked for potential double counts. Occasional deviations from this work plan were caused by logistic problems. For instance, the northern sites (site 9-13) were not accessible before 5 September, when we received notification that the mandatory mine clearing had been completed.

Estimations of the flight height of the birds were calibrated with the aid of laser binoculars (Geovid $10 \times 40$ and $7 \times 40$ ) and observers were trained using a $25 \mathrm{~kW}$ Furuno ship radar. The procedure was as follows: after an individual bird was identified by sight and by radar, the observer's estimate of the 


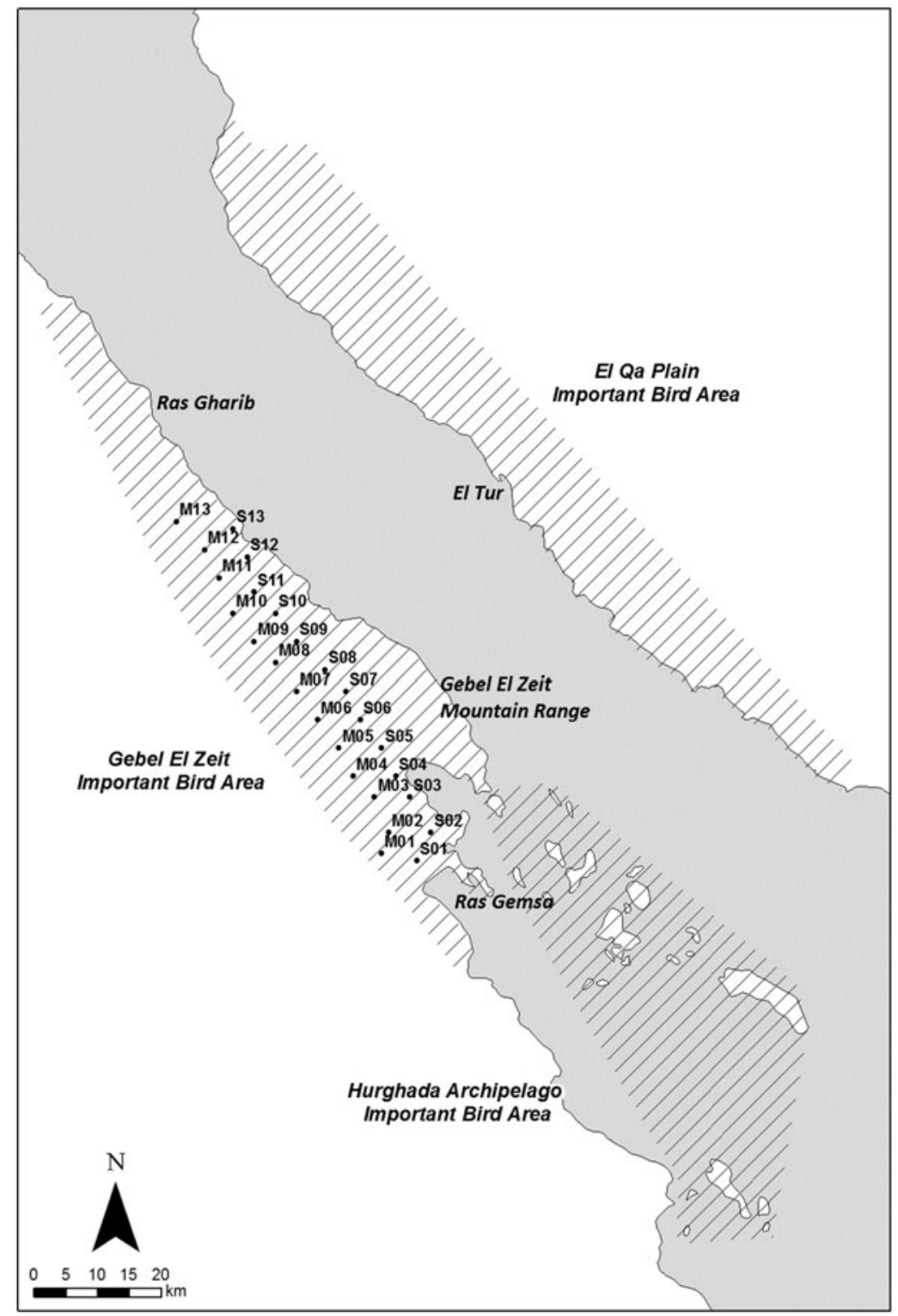

Figure 1. Position of the observation sites $\mathrm{M}_{1-13}$ and $\mathrm{S}_{1-13}$ and of the IBAs "Gebel El Zeit", "Hurghada Archipelago" and "El Qa Plain" (hatched) (produced by BirdLife International based on IBA information in the World Bird Database and information supplied by the author).

flight height was compared with the radar readings. The observers were instructed during systematic observations to estimate heights as closely as possible. In order to avoid a bias in the results, the observers were not informed of the evaluation categories later used to determine whether or not birds were endangered by wind turbines. Horizontal distances from the observer were calibrated wherever possible by reference to known distances to topographical features previously measured by means of GPS. Similarly, horizontal distances were estimated as closely 
as possible. In order not to bias the results, distance categories of the evaluation were not known to observers. During the first weeks, the composition of the teams was changed regularly in order to achieve standardised procedures and minimise differences between individual observers and between teams.

The following parameters were determined and documented: start and end times of observations at a site, species and number of birds, exact time of observation, flight direction, flight height above ground, distance and direction from the observer. Estimates were made when the birds were at the minimum distance from the observer. The observations were performed daily from 20 August to 29 October 2006. On 31 August, 2 September and 21 October no observations were performed. We did not interpolate numbers for these days but simply omitted them. The two teams performed the observations using $10 \mathrm{x} 4 \mathrm{O}$ binoculars and $20 \mathrm{x}$ to 6ox telescopes (for details see Hilgerloh 2009). The study area was under observation for a total of 453.6 hours, an average of 17.45 hours per site.

\section{Evaluation of daytime observations}

The raw data were evaluated at three levels. The first evaluation ignored the distance at which birds were recorded. Then, in order to assign the birds to a specific area, subsequent evaluations took account only of birds recorded within $2.5 \mathrm{~km}$ of the observer (first at any height and second only birds at up to $200 \mathrm{~m}$ ). According to Niemann (pers. comm.) the planned turbines were c.10om high.

Calculation of the mean direction of bird movements, the vector length and significance of uniformity of direction (Rayleigh test) were performed using the circular statistics program Oriana (Kovach Computing Services 2009). We used the number of independent sightings, which included both singles and groups of birds, rather then the total number of birds in analyses of flight directions. Only species with more than 15 records were included in the statistical analysis of migration direction and phenology.

In order to assess the global importance of the passage in this area, the percentage of the flyway population passing through the study area was extrapolated from the raw data; i.e. the total number of birds counted during the survey period. As observations were performed from sunrise to sunset during 70 days, the number of birds passing through the study area per season from sunrise to sunset (12 hours) during 70 days of migration was estimated. As the study area - c.10 $x$ $70 \mathrm{~km}$ - extends from NW to SE, birds migrating to the south-south-west will cross the study area on a front broader than $10 \mathrm{~km}$. As the northernmost part of the area is less frequented by migrants and as the start of observations in that area was delayed through mine-sweeping operations, for the extrapolations we assumed a migration front of $20 \mathrm{~km}$.

\section{Results}

In total, 145,432 soaring birds including 134,599 storks and 9,376 raptors were observed during systematic observations (Table 1). The White Stork Ciconia ciconia (91.4\%) was the most numerous species, followed by European Honey Buzzard Pernis apivorus (5.7\%), White Pelican Pelecanus onocrotalus (o.8\%) and Black Stork Ciconia nigra (0.9\%) (Table 1). All other species were observed in numbers below 400 individuals. Significant observations included the Near Threatened' Pallid Harrier Circus macrourus. Small numbers of the 'Endangered' Egyptian Vulture Neophron percnopterus and 'Vulnerable' Lesser Kestrel Falco naumanni were observed.

Within a radius of $2.5 \mathrm{~km}$ of the observers, 57,179 soaring birds were identified, including 50,238 storks and 6,413 raptors (Table 1). In general, birds were observed in greater numbers in the southern part of the study area than in the central and northern parts (Table 2; Figure 1). Lower numbers of White Storks were reported in the most northerly part and of raptors in the central part. However, many species, including Pallid Harrier, showed an even distribution throughout the study area. 
Table 1. Number of soaring birds observed at any distance, at distances up to $2.5 \mathrm{~km}$ and at heights at or below $200 \mathrm{~m}$ within a radius of $2.5 \mathrm{~km}$ at Zeit bay from August 20 to October 29.

\begin{tabular}{|c|c|c|c|c|}
\hline \multirow[b]{2}{*}{ Species } & \multirow[b]{2}{*}{ English name } & any distance & up to $2.5 \mathrm{~km}$ & \multirow{2}{*}{$\begin{array}{l}\text { up to } 2.5 \mathrm{~km} \\
\text { first } 200 \mathrm{~m}\end{array}$} \\
\hline & & \multicolumn{2}{|l|}{ all heights } & \\
\hline Phoenicopterus ruber & Greater Flamingo & 30 & 19 & 19 \\
\hline Ciconia nigra & Black Stork & 1,350 & 474 & 329 \\
\hline Ciconia ciconia & White Stork & 133,061 & 49,764 & 27,460 \\
\hline Plegadis falcinellus & Glossy Ibis & 35 & & \\
\hline Platalea leucorodia & Eurasian Spoonbill & 65 & 65 & 65 \\
\hline Nycticorax nycticorax & Black-crowned Night-heron & 15 & & \\
\hline Bubulcus ibis & Cattle Egret & 1 & 1 & 1 \\
\hline Ardea cinerea & Grey Heron & 56 & 46 & 46 \\
\hline Ardea purpurea & Purple Heron & 141 & 26 & 26 \\
\hline Ardea sp. & Ardea spec. & 3 & & \\
\hline Egretta gularis & Western Reef-egret & 3 & 3 & 3 \\
\hline Egretta sp. & Egret spec. & 5 & 1 & 1 \\
\hline Pelecanus onocrotalus & Great White Pelican & 1,140 & 212 & 53 \\
\hline Falco naumanni & Lesser Kestrel & 33 & 33 & 14 \\
\hline Falco tinnunculus & Common Kestrel & 19 & 19 & 18 \\
\hline F. naumanni/F. tinnunculus & Lesser Kestrel/Common Kestrel & 25 & 24 & 15 \\
\hline Falco vespertinus & Red-footed Falcon & 3 & 3 & 2 \\
\hline Falco subbuteo & Eurasian Hobby & 18 & 18 & 15 \\
\hline Falco biarmicus & Lanner Falcon & 1 & 1 & 1 \\
\hline Falco $p$. pelegrinoides & Barbary Falcon & 1 & 1 & 1 \\
\hline Falco sp. & Falcon sp. & 22 & 19 & 14 \\
\hline Pandion haliaetus & Osprey & 9 & 5 & 4 \\
\hline Pernis apivorus & European Honey-buzzard & 8,339 & 5,574 & 3,556 \\
\hline Milvus migrans & Black Kite & 56 & 47 & 29 \\
\hline Neophron percnopterus & Egyptian Vulture & 8 & 8 & 5 \\
\hline Circaetus gallicus & Short-toed Snake-eagle & 4 & 3 & 1 \\
\hline Circus aeruginosus & Western Marsh Harrier & 354 & 296 & 248 \\
\hline Circus macrourus & Pallid Harrier & 100 & 90 & 78 \\
\hline Circus pygargus & Montagu's Harrier & 86 & 78 & 71 \\
\hline C. macrourus/C. pygargus & $\begin{array}{l}\text { Pallid Harrier/ } \\
\text { Montagu's Harrier }\end{array}$ & 77 & 69 & 56 \\
\hline Circus sp. & Harrier sp. & 30 & 16 & 16 \\
\hline Accipiter brevipes & Levant Sparrowhawk & 17 & 17 & 8 \\
\hline Accipiter nisus & Eurasian Sparrowhawk & 6 & 6 & 4 \\
\hline A. brevipes or A. nisus & $\begin{array}{l}\text { Levant Sparrowhawk/ } \\
\text { Eurasian Sparrowhawk }\end{array}$ & 8 & 7 & 4 \\
\hline Buteo b. vulpinus & Steppe Buzzard & 38 & 29 & 12 \\
\hline Buteo rufinus & Long-legged Buzzard & 2 & 2 & 2 \\
\hline Buteo sp. & Buzzard sp. & 8 & 8 & 4 \\
\hline Aquila pomarina & Lesser Spotted Eagle & 6 & 6 & 5 \\
\hline Hieraetus pennatus & Booted Eagle & 5 & 5 & 3 \\
\hline Raptor sp. & Raptor sp. & 97 & 29 & 14 \\
\hline Merops apiaster & Eurasian Bee-eater & 155 & 155 & 45 \\
\hline Total & & 145,432 & 57,179 & 32,248 \\
\hline
\end{tabular}

The number of birds observed during systematic counts resting or flying at heights of up to $200 \mathrm{~m}$ was 32,248 , including 27,789 storks and 4,200 raptors (Table 1 ). This represents $55.3 \%$ of the storks and $65.5 \%$ of the raptors. Of this subset too, more birds were seen in the south of the study area than further north (Table 2), and the difference was much larger. At these heights, 
Table 2. Comparison of numbers of soaring birds per observation hour $(\mathrm{n} / \mathrm{h})$ at the most southern sites, the central and the northern sites of the study area at Zeit Bay.

\begin{tabular}{lccc}
\hline Sites & $1-4(\mathrm{n} / \mathrm{h})$ & $5-8(\mathrm{n} / \mathrm{h})$ & $9-13(\mathrm{n} / \mathrm{h})$ \\
\hline All heights & & & 41.7 \\
All soaring birds & 192.5 & 137.5 & 22.8 \\
White Stork & 169 & 130.8 & 14.9 \\
All raptors & 21.2 & 6.2 & 0.2 \\
Pallid Harrier & 0.2 & 0.2 & 32.2 \\
O-20om & & & 20.4 \\
All soaring birds & 138.9 & 38.5 & 9.7 \\
White Stork & 121 & 36.6 & 0.2 \\
All raptors & 16.3 & 1.8 & 0.2 \\
Pallid Harrier & 0.2 & & \\
\hline
\end{tabular}

soaring birds were 3.6 times more frequent in the southern than in the central part and even 4.3 times more frequent in the southern than the northern part of the study area (Table 2).

Of the birds seen at or below $200 \mathrm{~m} \mathrm{14,834}(46 \%)$ were resting on the ground (Table 1 ), of which $99 \%$ were storks. Nearly all of them were observed around the two southernmost sites along the road. In total 14,523 White Storks were seen resting in the southern part and 94 in the central and northern part of the study area (Table 2). Resting Greater Flamingos Phoenicopterus ruber, Eurasian Spoonbills Platalea leucorodia, Western Reef-egrets Egretta gularis and Grey Herons Ardea cinerea concentrated at the salt depression near site $\mathrm{S}_{13}$. Raptors were observed resting in small numbers $(n=29)$ scattered over the entire study area.

Black Storks actually observed accounted for $4.8 \%$ of the flyway population, White Storks for $33.3 \%$ and Great White Pelicans for 3.5\%. The extrapolation of the number of birds passing during the migration season through the study area suggests that it was used by $92 \%$ of the White Stork, $12 \%$ of the Black Stork, $5 \%$ of the White Pelican, $4 \%$ of the European Honey Buzzard and $2 \%$ of the Pallid Harrier flyway population.

Flight directions showed little variation between species, all being oriented towards a southsouth-west direction (Table 4). The flocks showed a high degree of uniformity of direction, but Black Kite Milvus migrans was the species in which the directions varied most (Table 4). The time of passage varied between the different species. Peak migration days in 2006 were between 28 August and ${ }_{13}$ October. The two most numerous species were early migrants (Table 4; Figure 2). A total of $90 \%$ of the White Storks had passed by 10 September and $90 \%$ of the European Honey Buzzards by 20 September. Accordingly, in October, little migration was recorded. However, from 6 October onwards, small groups of storks (a total of 33 White Storks in four flocks and one flock of 23 Black Storks) were recorded migrating to the north.

\section{Discussion}

This study documents the strong autumn migration of White Storks through the Zeit Bay IBA. The numbers observed represented $33 \%$ of the flyway population of White Storks and an extrapolated $92 \%$ of the flyway population (Table 3). The high percentage of the flyway population of White Storks observed crossing the study area during the autumn migration confirms previous studies according to which the main route of White Storks goes through Zeit Bay in both seasons (Creutz 1985, Schulz 1988, Leshem and Yom-Tov 1998, Berthold et al. 2001). Even White Storks that reached the southern tip of Sinai in autumn mostly turned back towards the NW, most probably to cross the Gulf of Suez at Zeit Bay (Celmins 1998 and pers. comm.). Although Zeit Bay is the main crossing point, some flocks crossed further south (pers. obs. during a visit to Tawila, situated $30 \mathrm{~km}$ south-east of Zeit Bay). Only exceptionally were storks observed at Suez and Bab-el-Mandeb (Bijlsma 1983, Welch and Welch 1988). 

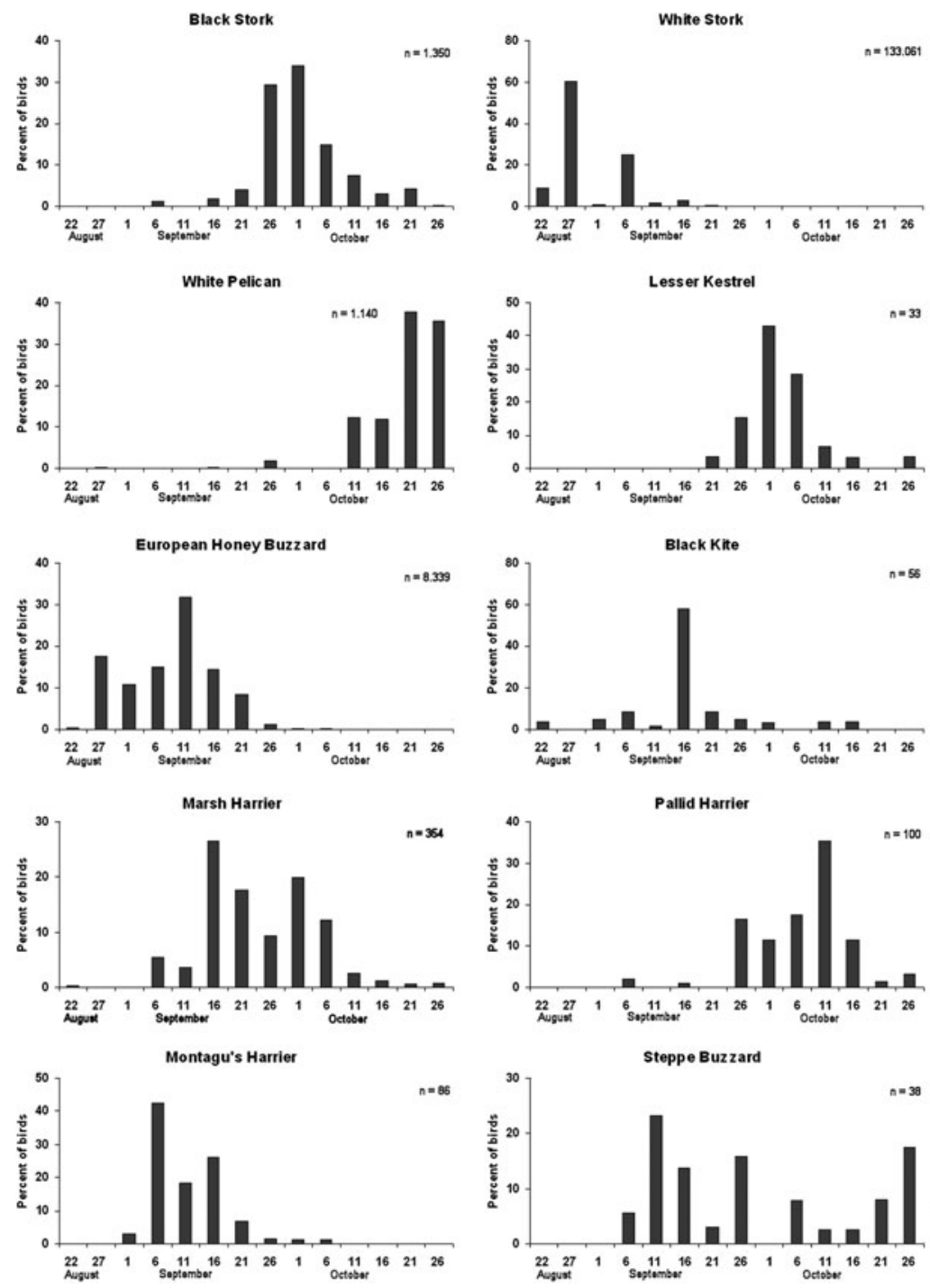

Figure 2. Timing of soaring and gliding migrants at Zeit Bay between 20 August and 28 October 2006. The graphs are based on the daily number of birds per observation hour.

The most numerous raptor species was the European Honey Buzzard, accounting for an extrapolated $4 \%$ of the flyway population (Table 3 ). As this species was observed at neither Bab-elMandeb nor Suez in more than comparatively small numbers, it seems likely that Honey Buzzards cross the Gulf of Suez. Since this species does not greatly depend on thermals, it is conceivable that it crosses the Gulf of Suez on a broader front, as other observations have also indicated (Christensen and Jensen 2002). Harriers were more evenly distributed over the study area than other species. This is consistent with the fact that these raptors, too, are not greatly dependant on thermals and are not narrow-front migrants. Although they were able to cross the Gulf of Suez anywhere, they nevertheless were more concentrated at Zeit Bay than at other migration 
Table 3. Number of observed birds and number of birds extrapolated for a migration season as percentage of the flyway population. Raptors, storks and pelicans observed in numbers exceeding 50 individuals are included in the table. ( ${ }^{*}$ Wetlands International 2006, ${ }^{* *}$ factsheet Birdlife International, for details see methods)

\begin{tabular}{|c|c|c|c|c|c|c|}
\hline Species & $\begin{array}{l}\text { Number } \\
\text { observed } \\
\text { (anydistance) }\end{array}$ & $\begin{array}{l}\text { Flyway } \\
\text { population }\end{array}$ & $\begin{array}{l}\text { \% of flyway } \\
\text { population } \\
\text { observed } \\
\text { (any distance) }\end{array}$ & $\begin{array}{l}\text { Birds } \\
\text { observed } \\
\text { per hour } \\
(\mathrm{r}=2.5 \mathrm{k}\end{array}$ & $\begin{array}{l}\text { Birds per } \\
\text { season } \\
\text { extrapolated } \\
20 \mathrm{~km}(\mathrm{~W}-\mathrm{E})\end{array}$ & $\begin{array}{l}\% \text { of } \\
\text { flyway } \\
\text { population } \\
\text { extrapolated }\end{array}$ \\
\hline Black Stork & 1,350 & $19,500-28,000^{*}$ & 4.82 & 1.04 & 3,494 & 12.48 \\
\hline White Stork & 133,061 & $390,000-400,000^{*}$ & 33.27 & 109.71 & 368,626 & 92.16 \\
\hline $\begin{array}{l}\text { Great White } \\
\text { Pelican }\end{array}$ & 1,140 & $20,100-32,900^{*}$ & $3 \cdot 47$ & 0.47 & 1,579 & 4.80 \\
\hline $\begin{array}{l}\text { European Honey } \\
\text { Buzzard }\end{array}$ & 8,339 & $350,000-1000,000^{* *}$ & 0.83 & 12.29 & 41,294 & 4.13 \\
\hline $\begin{array}{l}\text { Western Marsh } \\
\text { Harrier }\end{array}$ & 354 & $500,000-2,000, \mathrm{OOO}^{* *}$ & 0.02 & 0.65 & 2,184 & 0.11 \\
\hline Pallid Harrier & 100 & $18-30,000^{* *}$ & 0.33 & 0.21 & 706 & 2.35 \\
\hline Montagu's Harrier & 86 & $100,000^{* *}$ & 0.09 & 0.17 & 571 & 0.57 \\
\hline
\end{tabular}

observation sites (Bijlsma 1983, Welch and Welch 1988, Celmins 1998). The 'Near Threatened' Pallid Harrier was present with the highest percentage of the flyway population of harriers.

Great White Pelicans are known to migrate through Israel in considerable numbers (Shirihai 1996). At Zeit Bay we recorded only a part of the passage, as this species has a long migration period and we finished observations on 29 October, whereas in Israel the passage of the central $90 \%$ of migration did not end before 7 November (Leshem and Yom-Tov 1998). Nevertheless, we observed $5 \%$ of the flyway population at Zeit Bay whereas no Great White Pelicans were recorded at Suez or Bab-el-Mandeb. Therefore, we suspect that a significant proportion of the flyway population crosses the Gulf of Suez.

All the other large migrant species observed at Suez, Bab-el-Mandeb or Israel during autumn migration were seen in small numbers or not at all at Zeit Bay. Among them, the Steppe Eagle Aquila nipalensis with its loop migration is a well-studied species that enters the African continent either at Bab-el-Mandeb or at Suez and is consequently not expected at Zeit bay in autumn (Welch and Welch 1991, Meyburg et al. 2003, Meyburg et al. 2005), whereas in spring it is a regular migrant (Hilgerloh 2009). Egyptian Vultures seem to enter the African continent mainly at Suez and Bab-el-Mandeb and so only very small numbers were observed at Zeit Bay.

Levant Sparrowhawks Accipiter brevipes were observed in insignificant numbers at Zeit Bay. However they concentrated at the southern tip of Sinai migrating southwards (Celmins 1998). The Common Crane Grus grus was not observed in autumn at Zeit Bay. This was not surprising considering that this species was detected only in small numbers throughout Egypt (Goodman and Meininger 1989). However, at the southern tip of Sinai some hundreds were observed within four days in the first half of October (Celmins 1998). This was interpreted as the beginning of an expected strong migration. As in spring, Common Cranes cross Zeit Bay in huge numbers (Hilgerloh 2009), this species may have an autumn and spring route in this area similar to that of Levant Sparrowhawk.

With only White Pelicans recorded in any numbers, the passage in October was relatively light, the majority of early migrants, principally White Stork and European Honey Buzzard, having gone through by the end of September (Figure 2).

Unsurprisingly, after having lost height during a sea crossing, migrants prolong their low flight over the coastal plains or even land and stay over for a night. Consequently, the percentage of birds observed in the $\mathrm{O}-\mathbf{2 0 0} \mathrm{m}$ height band, was quite large as in spring (Hilgerloh 2009). This means that not once but twice per year they would be threatened by the presence of huge wind 
Table 4. Mean migration direction and vector length of the different species within a radius of $2.5 \mathrm{~km}$ from the observer. Date of median and peak migration day, numbers on peak day, percentage of all on peak day and total number. In White Stork and European Honey Buzzard the real median of passage may be earlier, as the passage of these species started before systematic observations began. Records refer to the number of independent sightings with identified flight direction. They include single flying or groups of birds. Only species with more than 15 records were included in the statistical analysis of migration directions and of phenology.

\begin{tabular}{|c|c|c|c|c|c|c|c|c|c|}
\hline & Records & $\begin{array}{l}\text { Mean } \\
\text { direction }(\mu)\end{array}$ & $\begin{array}{l}\text { Vector } \\
\text { length } r\end{array}$ & $\begin{array}{l}P \\
\text { (Rayleigh) }\end{array}$ & $n$ & Median & Peak & $\begin{array}{l}\text { Number } \\
\text { Peak day }\end{array}$ & $\begin{array}{l}\text { Peak as } \\
\% \text { of all }\end{array}$ \\
\hline Black Stork & 32 & 207.29 & 0.90 & $<0.001$ & 1350 & I Oct & I Oct & 322 & 23.85 \\
\hline White Stork & 110 & 194.15 & 0.81 & $<0.001$ & 133049 & 28 Aug & $28 \mathrm{Aug}$ & 65,620 & $49 \cdot 32$ \\
\hline Lesser Kestrel & 24 & 195.29 & 0.89 & $<0.001$ & 33 & 3 Oct & 3 Oct & 11 & $33 \cdot 3$ \\
\hline Eurasian Hobby & 16 & 199.04 & 0.79 & $<0.001$ & 17 & 26 Sep & 27 Sep & 3 & 17.6 \\
\hline $\begin{array}{l}\text { European Honey } \\
\text { Buzzard }\end{array}$ & 456 & 190.81 & 0.93 & $<0.001$ & 8339 & 10 Sep & 10 Sep & 2,633 & 31.57 \\
\hline Black Kite & 29 & 188.88 & 0.71 & $<0.001$ & 56 & 15 Sep & 15 Sep & 23 & 41.07 \\
\hline $\begin{array}{l}\text { Western Marsh } \\
\text { Harrier }\end{array}$ & 231 & 201.06 & 0.92 & $<0.001$ & 354 & 29 Sep & 29 Sep & 46 & 13.00 \\
\hline Pallid Harrier & 78 & 209.76 & 0.88 & $<0.001$ & 100 & $13 \mathrm{Oct}$ & $13 \mathrm{Oct}$ & 14 & 14.00 \\
\hline Montagu's Harrier & 57 & 202.90 & 0.93 & $<0.001$ & 86 & 8 Sep & 8 Sep & 17 & 19,77 \\
\hline Steppe Buzzard & 18 & 198.77 & 0.93 & $<0.001$ & 38 & 8 Sep & 8 Sep & 11 & 28.95 \\
\hline
\end{tabular}


farms in this area. Birds that try to avoid collisions with the rotors of the turbines have to revert to active flight, which is much more energy-consuming than soaring and gliding. This additional expenditure of energy could certainly lead to an increase in fatal casualties, not only at the wind farm site itself but also later on during migration. Conventions regarding the construction of wind farms clearly advise against any such developments in Important Bird Areas (Bern Convention 1979, Langston and Pullan 2003, Hoetker et al. 2004, Drewitt and Langston 2006, Langston 2006). As already put forward on the basis of analogous spring data (Hilgerloh 2009), the area should be kept free of all industrial development so as not to add to the already massive and acute dangers facing the birds along their migration route (Wilcove 2008).

\section{Acknowledgements}

We wish to thank the following ornithologists who carried out field work with us: J. Weinbecker, B. Weinbecker, C. Völlm, G. Pegram, G. Nikolaus and K. Gauger. We are grateful to two anonymous referees for valuable comments. K. Wilson improved the language. A. Abdelmageed provided support in Egypt and E. Niemann during the entire study. The Deutsche Entwicklungsbank (KfW) financed the field work and the New and Renewable Energy Authority of Egypt (NREA) gave permission to publish these data.

\section{References}

Baha El Din, S. (1999) Directory of important bird areas in Egypt. Cambridge, UK: BirdLife International.

Bern Convention (1979) Convention on the conservation of European wildlife and natural habitats. Strasbourg: Council of Europe. CETS No. 104.

Berthold, P., van den Bossche, W., Fiedler, W., Gorney, E., Kaatz, M., Leshem, Y. Nowak, E. and Querner, U. (2001) Der Zug des Weißstorchs (Ciconia ciconia) eine besondere Zugform auf Grund neuer Ergebnisse. J. Ornithol. 142: 73-92.

Bijlsma, R. G. (1983) The migration of raptors near Suez, Egypt, autumn 1981. Sandgrouse 5: 19-44.

Bildstein, K. (2006) Migrating raptors of the world, their ecology and conservation. Ithaca, NY, USA: Cornell University Press.

Celmins, A. (1998) South Sinai bird migration survey 14 August - 14 October. Sharmel-Sheikh: Ras Mohammed National Park. Unpublished report.

Christensen, K. D. and Jensen, F. P. (2002) Atlas of bird migration at the Gulf of Suez, Egypt. Copenhagen, Denmark: Ministry of Foreign Affairs and Danida Ornis Consult Ltd.

Creutz, G. (1985) Der Weißstorch. Wittenberg Lutherstadt, Germany: A. Ziemen Verlag.
Drewitt, A. L. and Langston, R. H. W. (2006) Assessing the impacts of wind farms on birds. Ibis 148: 29-42.

Goodman, S. M. and Meininger, P. L., eds. (1989) The birds of Egypt. Oxford, UK: Oxford University Press.

Grieve, A. (1996) Spring raptor movements at Gebel el Zeit, Egypt. Sandgrouse 18: 61-63.

Hilgerloh, G. (2008) Die Wüste an der Bucht von El Zeit/Ägypten: ein Flaschenhals des Vogelzugs von globaler Bedeutung. Vogelwarte 46: 361.

Hilgerloh, G. (2009) The desert at Zeit Bay/ Egypt: a critical bird migration bottleneck area of global importance. Bird Conserv. Int. 19: $358-352$.

Hilgerloh, G., Weinbecker, J. and Weiss, I. (2009) The timing of spring passage of soaring birds at Zeit Bay/Egypt. Sandgrouse 31: 26-35.

Hoetker, H., Thomsen, K.-M. and Koester, H. (2004) Auswirkungen regenerativer Energiegewinnung auf die biologische Vielfalt am Beispiel der Vögel und der Fledermäuse - Fakten, Wissenslücken, Anforderungen an die Forschung, ornithologische Kriterien zum Ausbau von regenerativen Energiegewinnungsformen. Berlin, Germany: NABUDeutschland. 
Kovach Computing Services (2009) Circular statistics program ORIANA, Version 3. Anglesey, UK: Kovach Computing Services.

Langston, R. H.W. (2006) Wind, fire and water: renewable energy and birds. Proceedings of the British Ornithologists' Union annual spring conference 2005, University of Leicester, 1-3 April 2005. Ibis 148: 1-3.

Langston, R. H. W. and Pullan, J. D. (2003) Windfarms and birds: An analysis of the effects of windfarms on birds, and guidance on environmental assessment criteria and site selection issues. Strasbourg: BirdLife International on behalf of the Bern Convention.

Leshem, Y. and Yom-Tov, Y. (1996) Routes of migrating soaring birds. Ibis 140: 41-52.

Meyburg, B.-U., Paillat, P. and Meyburg, C. (2003) Migration routes of Steppe Eagles between Asia and Africa: a study by means of satellite telemetry. Condor 105: 219-227.

Meyburg, B.-U., Paillat, P., Meyburg, C. and Graszynski, K. (2005) Der Zug des Steppenadlers. Der Falke 52: 12-17.

Newton, I. (2008) The migration ecology of birds. Heidelberg, Germany: Academic Press.

Shirihai, H. (1996) Birds of Israel. London, UK: Academic Press.
Shirihai, H., Yosef, R., Alon, D., Kirwan, G. V. and Spaar, R. (200o) Raptor migration in Israel and the Middle East. A summary of 30 years of field research. Eilat, Israel: IBRC.

Schulz, H. (1988) Weißstorchzug. Ökologie, Gefährdung und Schutz des Weißstorchs in Afrika und Nahost. Weikersheim, Germany: WWF-Umweltforschung.

Tammens, R. (2008) Spektakulärer Vogelzug über der ägyptischen Wüste. Der Falke 55: 9-13.

Telleria, J.-L. 2009. Potential impacts of wind farms on migratory birds crossing Spain. Bird Conserv. Int. 19: 131-136.

Welch, G. and Welch, H. (1988) The autumn migration of raptors and other soaring birds across the Bab-el-Mandeb straits. Sandgrouse 10: 26-51.

Welch, G. and Welch, H. (1991) Autumn migration of the Steppe Eagle Aquila nipalensis. Sandgrouse 13: 24-33.

Wetlands International (2006) Waterbird population estimates - fourth edition. Wageningen, The Netherlands: Wetlands International.

Wilcove, D. S. (2008) No way home. The decline of the world's great animal migration. Washington: Island Press.

\section{GUDRUN HILGERLOH*}

Institute of Zoology, Johannes Gutenberg University, Johannes v. Müllerweg 6, D-55128 Mainz, Germany.

\section{ANDREAS MICHALIK}

University of Osnabrueck, Department of Biology/Chemistry, Experimental Ecology Group, Barbarastr. 11, D-49076 Osnabrueck, Germany.

BERND RADDATZ

Dudenstr. 38, D-10965 Berlin Germany.

*Author for correspondence; e-mail: gudrun@hilgerloh.eu

Received 29 June 2009; revision accepted 13 April 2011; Published online 26 October 2011 